\section{Ewelina Feldman Kołodziejuk}

University of Białystok, Poland
2020, Vol. 17 (1), 67-85(164)

revije.ff.uni-lj.si/elope

https://doi.org/10.4312/elope.17.1.67-85

UDC: $821.111(71) .09-31$ Atwood M.:141.72

\title{
Mothers, Daughters, Sisters: The Intergenerational Transmission of Womanhood in Margaret Atwood's The Handmaid's Tale and The Testaments
}

\begin{abstract}
The article reads The Handmaid's Tale and The Testaments as a response to changes in the feminist movement. Less radical than their mothers' generation, second-wave feminists' daughters often abandoned the struggle for equality and focused on homemaking. Nevertheless, the 1990s saw a resurgence of the women's liberation movement known as the third wave. These feminism(s) significantly redefined the notion of womanhood and emphasised the diversity of the female. After 2010, critics argue, third-wave feminism entered the fourth wave. This analysis of The Handmaid's Tale focuses on Offred's relationship with her mother, which is representative of the wider phenomenon of the Backlash. It investigates how the mother and her generation influenced the maternal choices of the Handmaid and discusses the trauma of child removal suffered by Offred. The final section examines The Testaments through the lens of third-wave feminism and analyzes the plight of Offred's daughters, focusing on their attitudes towards womanhood and maternity.
\end{abstract}

Keywords: feminism; The Handmaid's Tale; The Testaments; Margaret Atwood

\section{Matere, hčere, sestre: Medgeneracijski prenos ženskosti v romanih Deklina zgodba in Testamenti Margaret Atwood}

\author{
POVZETEK
}

Članek obravnava romana Deklina zgodba in Testamenti kot odziv na spremembe v feminističnem gibanju. Hčere feministk drugega vala, ki so bile manj radikalne kot njihove matere, so pogosto opustile boj za enakost in se osredotočile na gospodinjstvo. Kljub temu smo bili v devetdesetih letih dvajsetega stoletja priča ponovni oživitvi ženskega osvobodilnega gibanja, ki ga imenujemo tretji val feminizma. Ti feminizmi so bistveno preoblikovali idejo ženskosti in poudarili raznovrstnost žensk. Kritiki trdijo, da je po letu 2010 tretji val feminizma vstopil v četrti val. Ta analiza romana Deklina zgodba se osredotoča na Offredin odnos s svojo materjo, ki je reprezentativen za širši pojav Nasprotovanja. Preiskuje, kako sta mati in njena generacija vplivali na odločitve o materinstvu Dekel in obravnava travmo premestitve otroka, ki jo je trpela Offred. Zadnji del preučuje roman Testamenti skozi prizmo tretjega vala feminizma in analizira težek položaj Offredinih hčera ter se osredotoča na njun odnos do ženskosti in materinstva.

Ključne besede: feminizem; Deklina zgodba; Testamenti; Margaret Atwood 


\section{Introduction}

The novel which gained Atwood the status of literary icon is undoubtedly The Handmaid's Tale, published in 1985. Thanks to a successful TV series adaptation released in 2017, currently in its fourth season, The Handmaid's Tale has been enjoying a spectacular renaissance. Its mass popularity has resulted in the appropriation of the red outfits of the Handmaids, worn along with a white winged headdress, by female protesters worldwide in order to demonstrate the thin line that separates some current political states from the Republic of Gilead (Atwood 2019b). Atwood's quasi-Latin message Nolite te bastardes carborundorum (Don't let the bastards grind you down) was unknown to the general public a few years ago, but is now displayed on protest banners. That the novel resonates with so many readers and protesters across the globe is rather despondent news, for it testifies to the ongoing breaches of human rights and commodification of lives in the name of a higher religious order. The Testaments (2019) restores hope in humanity and the power of sisterhood.

Set fifteen years after the closing scene of The Handmaid's Tale, The Testaments reveals the circumstances of Gilead's fall. The novel is an interspersed first-person narrative from three characters: Aunt Lydia, who turns out to be a spy cooperating with the Mayday resistance and Offred's two daughters: Agnes Jemima, born in the pre-Gilead world and taken from her mother at five, and Nicole, smuggled as an infant out of Gilead to Canada. All three, closely orchestrated by Aunt Lydia, succeed in smuggling evidence that exposes the corrupt nature of leading Commanders and eventually helps to overthrow the Gileadean regime. In my analysis of The Handmaid's Tale I focus on the relationship between Offred and her mother, which is representative of the wider phenomenon of the Backlash. I investigate how the mother and her generation influenced the maternal choices of the titular Handmaid and discuss the trauma of child removal suffered by Offred. In the final section of the study I examine The Testaments through the lens of third-wave feminism and analyze the plight of Offred's daughters, focusing on their attitudes towards womanhood and maternity.

\section{Offred as a Daughter: The Mother-Daughter Conflict Set Against the Backlash Effect}

The relationship between Offred and her mother is set against a wider socio-historical background involving conflict between second-wave feminists and their daughters. In support of this thesis, Shirley Neuman maintains that "Offred, in short, is a fictional product of 1970s feminism, and she finds herself in a situation that is a fictional realization of the backlash against women's rights that gathered force during the early 1980 "' $(2006,858)$. That The Handmaid's Tale is a critique of second-wave feminism was also acknowledged by Coral Ann Howells in the 1996 edition of her Margaret Atwood: "Yet the novel exceeds definitions of political correctness and has provoked much unease in its critique of second wave North American feminism" $(1996,127){ }^{1}$

The name given to this new movement, which eventually came to be labelled postfeminism, posed problems due to the semantic ambiguity of the prefix "post," which may suggest either

Interestingly, the sentence was deleted from the second edition of Howells' book (2005). 
an end to second-wave feminism or its natural evolution into a new form, building on the achievements of the former movement (Gamble 2006, 37). The unclear status of postfeminism also stemmed from the fact that, while it recognized feminist gains in gender equality, which initially gave it a veneer of feminist thinking, it simultaneously claimed the redundancy of further struggle. Instead, it encouraged "women to embark on projects of individualized self-definition and privatized self-expression exemplified in the celebration of lifestyle and consumption choices" (Budgeon 2011b, 281). In their anthology Third Wave Agenda (1997), Leslie Heywood and Jennifer Drake strongly object to the labelling of third-wave feminism as postfeminism: "Let us be clear: 'postfeminist' characterizes a group of young, conservative feminists who explicitly define themselves against and criticize feminists of the second wave" $(1997,1)$. With time, most critics ultimately drew a clear distinction between postfeminism, understood as "a media-driven spectacle of anti-feminism," and third-wave feminism, which was considered "a natural progression of feminist thought towards a politics of diversity" (Tolan 2007, 47). ${ }^{2}$ Thanks to the publication of Susan Faludi's Backlash: The Undeclared War Against American Women (1991), which portrays postfeminism as a significant relapse in the development of the women's liberation movement, the widespread postfeminist propaganda came to be called the Backlash.

The Handmaid's Tale is not solely a critique of theocracy and the rising popularity of rightwing sentiments but also a response to a crisis in the feminist movement. Less radical than their mothers' generation, second-wave feminists' daughters veered to the right, aided by those media that declared a postfeminist era and whose cover stories consistently reiterated women's "failure to find husbands, get pregnant, or properly bond with their children" (Faludi 2006, 93-94). As Faludi observes, "the absence of real women in a news account that is allegedly about real women is a hallmark of ' 80 s backlash journalism. The press delivered the backlash to the public through a series of 'trend stories,' articles that claimed to divine sweeping shifts in female social behavior while providing little in the way of evidence to support their generalizations" (2006, 93). Trend stories repeatedly showed professional women as torn between their career and children or plagued by an infertility epidemic.

Though highly manipulated, the claims such ubiquitous female narratives made about the impossibility of "having it all" were hard to refute, for even such an established feminist figure as Alice Rossi argued that feminism had gone too far in its neglect of inborn biological differences between sexes. Her article "A Biosocial Perspective on Parenting" (1977), which was pilloried by Nancy Chodorow (1999, 18-20), exalted the connection between female sexual gratification and birthing, while simultaneously pointing out the inadequacy of public child-care programs and arguing that "little has yet been done to disturb the idea that under the best of all circumstances, the best place for young children is in the home under the mother's care" (Rossi 1977, 22). Such findings gave ammunition to the New Right, which, "countering women's independence and autonomy, [...] called for the restoration of women's traditional roles and for the return of women to the home" (Bouson 1993, 135).

Yet, some academics insist on rearticulating postfeminism as third-wave on the grounds that "definitions of and assumptions about both third-wave and postfeminism in fact often overlap in a variety of ways, highlighting a number of similarities and continuities between these two ostensibly different contemporary feminisms and challenging the very distinction Heywood and Drake insist on" (Braithwaite 2002, 342). 
Televangelists who rose to fame and power at that time proclaimed that "feminists encourage women to leave their husbands, kill their children, practice witchcraft, destroy capitalism and become lesbians" (Neuman 2006, 860). Since media coverage often portrayed feminists primarily as single, man-hating and child-killing militants, it is hardly surprising that their daughters' generation could no longer identify with the movement. A new ideal for women arose, embodied by Phyllis Schlafly, author of The Power of the Positive Woman (1977).

Schlafly, who is now generally recognized as the face of anti-feminism, ${ }^{3}$ exhorted women to embrace gender differences and make the most of them. She was the founder of the STOP ERA (The Equal Rights Amendment) movement, which strongly opposed the ratification of the amendment to guarantee equal legal rights for all American citizens regardless of sex. While supporters of the ERA, who were predominantly members of women's liberation movements, "sought the eradication of those gendered rules and norms that confined women to a life within the home," its antagonists claimed that "women were destined to be wives and mothers, and their domestic roles actually freed them from the drudgeries and dangers of the office, the factory, and the military, among other male-dominated venues" (Miller 2015, 279). In her public addresses as well as in her writing, Schlafly advocated the traditional role division of working husbands and stay-at-home wives, with single women mostly relegated to the posts of teachers and nurses, as "the schoolchild or the patient of any age provides an outlet for a woman to express her natural maternal need" $(2003,325)$. Schlafly declares that "The Positive Woman looks upon her femaleness and fertility as part of her purpose, her potential, and her power. She rejoices that she has a capability for creativity that men can never have" $(2003,324)$; Atwood, taking these presumptions to the extreme, constructs the world of The Handmaid's Tale, in which fertility is a rather dubious power.

At the heart of postfeminism lay the resentment that equal opportunities, the goal of second-wave feminism, meant more work, responsibilities and incessant frustration at not being able to reconcile childcare and career. Moreover, postfeminists accused their mothers of having been sacrificed at the altar of the feminist struggle, which Badinter sums up in the following words:

In pursuit of your independence, you sacrificed me as well. You didn't give me enough love, enough care, enough time. You were always in a hurry and often tired; you thought the quality of the time you spent with me was more important than the quantity. The truth is, I was not your top priority and you were not a good mother. I won't do the same with my children. $(2011,108)$

This approach, and simultaneously reproach, is evident in the relationship between Offred and her activist mother, who was always involved in some scheme, rushing to a rally or a meeting. One of the moments Offred recalls, lying in her bedroom at the Commander's house, is that of a promised walk in the park with her mother: "she said we were going to feed the ducks. But there were some women burning books, that's what she was really there

Even in her eighties Phyllis Schlafly did not alter her harsh view of feminists and still saw them as "anti-family, antichildren, and pro-abortion", maintaining that "women's libbers view the home as a prison and the wife and mother as a slave" (Allit 2016). 
for. To see her friends; shed lied to me, Saturdays were supposed to be my day. I turned away from her, sulking, towards the ducks" $(1985,48)$. Always busy, fighting for the cause, Offred's mother obviously believed in the notion of quality time, making up for the rest of the week's inattention on Saturdays. However, even on those days she found it hard to resist the temptation of joining her friends in burning pornographic magazines.

Owing to her mother's active involvement in the feminist struggle, their life included constant change of apartments, granting Offred little stability. "I wanted from her a life more ceremonious, less subject to makeshift and decampment," the Handmaid confesses (1985, 190). Unlike their mothers, postfeminists believed that children needed a lot of care and attention as well as their mother's presence. Family and home were their priority, even if also pursuing careers. Home cooking was an expression of tender loving care that Offred seems to miss. The smell of home-made bread at the Commander's house evokes memories from her pre-Gilead past: "The kitchen smells of yeast, a nostalgic smell. It reminds me of other kitchens, kitchens that were mine. It smells of mothers; although my own mother did not make bread. It smells of me, in former times, when I was a mother" (1985, 57). This succinct, matter-of-fact comment summarizes the shift in an attitude towards motherhood that Offred must have consciously made herself. She refused to be like her mother and resolved to be a better parent to her daughter, bread-making thus being a metaphor for maternal love. Though she did not entirely discard her mother's ideals and her fight for gender equality, Offred had a different attitude towards men. While her mother dismissed men on principle, Offred believed in partnership and love. According to Offred's mother,

there is something missing in them, even the nice ones. It's like they're permanently absent-minded, like they can't quite remember who they are. They look at the sky too much. They lose touch with their feet. They aren't a patch on a woman except they're better at fixing cars and playing football, just what we need for the better improvement of the human race, right? $(1985,131)$

The attitude of her mother's more radical friends can be summarized in Ehrenreich's words: "[they] tended to see all of history as a male assault on women and, by proxy, on nature itself. Hence rape, hence acid rain, hence six-inch high heels, hence the arms race, hence (obviously) the scourge of pornography" (quoted in Bloom 2004, 78). This "female-only" ideology representative of some radical activists who wished to eradicate men from their lives gave ammunition to postfeminism, which sought to break with feminism on the grounds that it was both anti-male and anti-family. The extremity of these radical feminist views is derided by Commander Judd, who asks Aunt Lydia to help him "organize the separate sphere - the sphere for women" (Testaments 2019, 175). As Fiona Tolan $(2005,19)$ argues, the novel is an intentional revision of the feminist movement: "By juxtaposing flashbacks of 1970s feminist activism with current descriptions of Gilead's totalitarianism, each informs the other so that The Handmaid's Tale depicts a dystopian society that has unconsciously and paradoxically met certain feminist demands."

However, through reminiscences of Offred's past with Luke, Atwood demonstrates that a fulfilling partnership between a man and a woman is feasible. As Amin Malak aptly notes, "the book's feminism, despite condemning male misogynous mentality, upholds and cherishes 
a man-woman axis; here, feminism functions inclusively rather than exclusively, poignantly rather than stridently, humanely rather than cynically" $(1987,15)$. Feminism, Atwood seems to be saying, is neither what second-wave radicals proclaimed nor what postfeminists declared it to be. Feminism is a belief in equality that must be based on the mutual respect of sexes, which rejects retaliation and exclusion of the opposite sex. "I'm defining my feminism as human equality and freedom of choice," Atwood states (quoted in Brans 2006, 81). Seeing that her mother's militant attitudes were partly responsible for her loneliness, to which she occasionally admitted, Offred does not want to perpetuate her parent's mistakes:

I admired my mother in some ways, although things between us were never easy. She expected too much from me, I felt. She expected me to vindicate her life for her, and the choices she'd made. I didn't want to live my life on her terms. I didn't want to be a model offspring, the incarnation of her ideas. We used to fight about that. I am not your justification for existence, I said to her once. $(1985,132)$

Maternal expectations of daughters, even if not overtly communicated, are inherent in a mother-daughter dyad (Alford and Harrigan 2019). In the case of Offred's mother's generation, the historical context of the equal rights movement made these even more prominent and intense. Having redefined the traditional notion of woman as wife and mother, second-wave feminists found the next generation's traditional choices exasperating. The next generation of women was supposed to continue the struggle against the still present gender bias rather than confine themselves anew to home and childbearing, an idea satirized through the women's confinement in the Republic of Gilead.

Unlike her mother, who chose motherhood against her generation's objections, Offred saw parenthood as a natural progression in a relationship. Along with Luke, she dreamt of buying a big house with a garden and swings for children. Together they awaited their daughter's birth, for which they most likely prepared, since they were familiar with the latest prenatal research: "Lying in bed, with Luke, his hand on my rounded belly. The three of us, in bed, she kicking, turning over within me. Thunderstorm outside the window, that's why she's awake, they can hear, they sleep, they can be startled, even there in the soothing of the heart, like waves on the shore around them" $(1985,113)$. In setting up a traditional family, parents plus child, Offred let her mother down. "You're just a backlash," Offred's mother would say to her, adding, "History will absolve me" $(1985,131)$. It needs to be reiterated that in the debate between second-wave feminists and their postfeminist daughters, Atwood does not take sides. What she seems to advocate is free choice. Motherhood should be a woman's choice, not subject to external pressure. No woman should be forced to become a mother or deprived of this possibility. In an interview with Jo Brans $(2006,81)$ conducted in 1982, three years before the publication of The Handmaid's Tale, Atwood clarifies her point on pregnancy and motherhood in the following manner: "Remember that I'm old enough to remember the time when women were told they had to get pregnant and have babies in order to 'fulfill their femininity.' And I didn't like that either. Nor do I like women being told that they oughtn't to get pregnant, that it's anti-feminist to get pregnant. I don't like that either." ${ }^{\prime 4}$

4 This assertion demonstrates how Atwood's attitude towards pregnancy overlaps with Cixous's (1976, 890) conviction: "Either you want a kid or you don't - that's your business." 
Once rid of her maternal responsibilities by Offred's maturity, her mother led the life of a vagabond, chasing her feminist goals and ideals. Preoccupied with serious issues, she could not be bothered with the mundane details of everyday existence. Constantly between apartments, she frequently visited Offred and Luke to use their washer-dryer or borrow a pot. "She breezed in and out of my house as if I were the mother and she were the child" $(1985,264)$. Second-wave feminist mothers are frequently portrayed as unconcerned with their children's well-being, their portrayals reminiscent either of carefree, irresponsible hippies with the wind in their hair or militant guerrillas with stern faces.

Unsurprisingly, motherhood was a particularly difficult decision for second-wave feminists, as it was generally considered to be the main source of oppression in women's lives. Some activists went so far as to treat this choice in terms of betrayal of the movement. Furthermore, single parenthood, though no longer carrying the stigma of past days, was not a widespread phenomenon either. Offred's mother attests to that:

I had you when I was thirty-seven, my mother said. It was a risk, you could have been deformed or something. You were a wanted child, all right, and I did get shit from some quarters! My oldest buddy Tricia Foreman accused me of being pronatalist, the bitch. [...] And stuff about how hard it was to be a single parent. [...] At the hospital they wrote down "Aged Primipara" on the chart, I caught them in the act. That's what they call you when it's your first baby over thirty, over thirty for godsake. $(1985,130)$

Becoming a mother, a woman suddenly becomes "a national resource" $(1985,75)$, to use Offred's bitter expression. Doctors, psychologists, sociologists and politicians proclaim what is good and what is bad for a prospective mother, and at what age she should bear children. Later they determine how she should raise and feed the baby so that it grows up to be - depending on the current trend - a perfect or perfectly happy citizen. These are the very attitudes Offred's mother's generation of women combatted and were therefore deeply disappointed when their daughters decided to glorify motherhood and the feminine. Unlike second-wave feminists, who strongly accentuated the similarities between the sexes and urged gender equality, postfeminists took pride in the feminine and their biological uniqueness; a woman's body became the source of primeval power that manifested itself through menstruation, pregnancy, and childbirth (Badinter 2011, 57).

This glorification of motherhood and its biological aspects takes a caricature form in The Handmaid's Tale, in the scene of Janine's labour, which is a communal ritual performed by all the Handmaids, and which proceeds naturally without medical intervention. Obstetricians are kept at bay in an Emerge van parked outside the house, as "they are only allowed in if it can't be helped" $(1985,124)$. Through chanting and paced breathing, not only do Handmaids help Janine deliver her baby, but they also experience the birth themselves, a mechanism which is weirdly reminiscent of collective hysteria:

It's coming, it's coming, like a bugle, a call to arms, like a wall falling, we can feel it like a heavy stone moving down pulled down inside us, we think we will burst. We grip each other's hands, we are no longer single. [...] My breasts are painful, they're leaking a little. Fake milk, it happens this way with some of us. [...] We ache. Each of us holds in her lap a phantom, a ghost baby. $(1985,135,137)$ 
The fully natural birth and subsequent breastfeeding became a must for the postfeminist movement, which in extreme cases turned into tyranny. Escaping the dictatorship of obstetricians and opposing the total medicalization of labour, postfeminists rejected the epidural and the milk bottle, attainments which made the physiological aspects of motherhood less painful and infant care more bearable for many. Even though already Pope Pius XII advocated pain-free labour, many thought that pain was inherent to childbearing, and that it guaranteed the proper formation of the mother-child bond, which was biological in nature. Surprisingly, some declared feminists espoused that view, too, among them, Helen Deutsch. A specialist in female psychology, Deutsch maintained that pain and suffering mark key stages in a woman's development, and without experiencing pain, the mother will not be capable of cuddling her newborn, and thus will be incapable of becoming a mother (Ducret 2016, 315). Freud's famous "Anatomy is destiny" seems to reverberate in Deutsch's reasoning to the same extent to which it permeates Gilead's doctrines.

The scene depicting Janine's natural birth clearly derides the vision of labour prescribed by postfeminists, as does Ofkyle's death in labour in The Testaments. Nevertheless, the turn towards natural birth was a reaction to the over-medicalization of labour that reduced the role of an active child-bearer to that of a passive patient expected to comply with her obstetrician's decrees. This often resulted in unnecessary medical interventions, such as $\mathrm{C}$-sections, forceps intervention, routine epidurals and episiotomies (Wolf 2003, 17). A graphic, yet most likely realistic vision of the medicalized birth of former times is shown in a film broadcast to the Handmaids by Aunt Lydia to prove the superiority of a wholly natural birth:

A pregnant woman, wired up to a machine, electrodes coming out of her every which way so that she looked like a broken robot, an intravenous drip feeding into her arm. Some man with a searchlight looking up between her legs, where she'd been shaved, a mere beardless girl, a trayful of bright sterilized knives, everyone with masks on. A cooperative patient. Once they drugged women, induced labor, cut them open, sewed them up. $(1985,124)$

Naturally, no generation of women consciously espoused this vision of labour either, but compromise between these two versions is possible. Offred herself seems to have happy memories of her own labour, which was neither excessively medicalized nor completely natural. It was probably close to the labour most women in the western world experience nowadays, under the supervision of a midwife and/or obstetrician, and in the presence of a partner: "What I remember is Luke, with me in hospital, standing beside my head, holding my hand, in the green gown and white mask they gave him. Oh, he said, Oh Jesus, breath coming out in wonder. That night he couldn't go to sleep at all, he said, he was so high" $(1985,136)$.

Though the term "Bildungsroman" is not commonly used with reference to The Handmaid's Tale, it is a novel about the protagonist's self-development and increase in self-awareness. At the beginning of the narrative, and even more so in the pre-Gilead flashbacks, Offred appears ignorant and uninterested in the broader structures beyond her family circle. Her memories paint a picture of a complacent, unreflective professional woman who took for granted her career and her family. "How were we to know we were happy?" $(1985,61)$ she asks afterwards. 
Not until she has been deprived of everything, including her daughter, can Offred commence the process of maturation. The things she progressively notes during her walks and scarce confidential talks with other Handmaids testify to her increased political awareness. Apart from the description of recent events, her narrative starts to offer a subversive commentary on current affairs. The novel transforms from an individual survivor narrative into a chronicle of political dissent, which Neuman confirms, saying that Offred's commentary "shows her as having gained political awareness and as reassessing her earlier more individualist positions. In her thoughts, for example, she engages in a rich dialogue with her mother, recollecting her earlier negative reactions to her mother's feminist activism but also learning to acknowledge some ways in which her mother was right" (2006, 861-62).

The above observation exemplifies how the daughter's self-identity is constantly shaped with reference to her mother. Offred's mother is most likely dead by now, yet their relationship continues. The memory of her late mother acts as an entity within the daughter's psyche that enables intergenerational transmission even posthumously. A specialist in bereavement, Christopher Hall (2011), acknowledges that

after a death bonds with the deceased do not necessarily have to be severed, [...] there is a potentially healthy role for maintaining continuing bonds with the deceased. This idea represents recognition that death ends a life, not necessarily a relationship. Rather than 'saying goodbye' or seeking closure, there exists the possibility of the deceased being both present and absent. The development of this bond is conscious, dynamic and changing.

The discovery of new things in the process of maturation or revaluation of former stances may occur as a result of the ongoing relationship with the deceased. The memory of past conversations may uncover new layers of meaning that were hidden by the interlocutor's bias. Since all knowledge is situated, it will always be determined by one's circumstances. The pre-Gilead Offred is not the Offred from the main narrative, who ultimately comes to realize that neither she nor her mother had a monopoly on truth - her mother being blinded by her disdain for men and total negation of traditional values, and Offred blinded by "willed ignorance" (Neuman 2006, 862) and discarding female solidarity. "Before the Republic of Gilead's oppressive regime came to power, Offred lived a life of political complacency" and failed to acknowledge something that lay at the core of her mother's creed: the personal is political (Hogsette 1997, 275).

Though Offred is an adult and a mother by the onset of the novel, she has not completed her process of maturation, for she is still in the infantile phase of blaming the mother. In reminiscences of her parent, Offred initially enumerates situations in which her mother failed her as a parent, juxtaposing her mother's political involvement (portrayed as child neglect) with her own devotion to her daughter and partner. In consequence, she knowingly models her motherhood through the negation of her mother's choices. Not until she is deprived of her daughter and enslaved by the glorification of motherhood underpinning the Republic of Gilead does Offred begin to question the cultural ideology of motherhood. She painfully realizes that a woman has the right to exist outside the maternal role, and that a mother, too, has the right to function outside the mother-child dyad. Ultimately, she leaves her infantile 
phase of mother-blaming and starts the process of maturation. Nancy Chodorow elucidates this development:

For the infant, the mother is not someone with her own life, wants, needs, history, other social relationships, work. She is known only in her capacity as mother. Growing up means learning that she, like other people in one's life, has and wants a life of her own, and that loving her means recognizing her subjectivity and appreciating her separateness. But people have trouble doing this and continue, condoned and supported by the ideology about mothers they subsequently learn, to experience mothers solely as people who did or did not live up to their child's expectations. $(1989,90)$

Despite their upheavals, Offred and her mother have managed to develop a secure attachment that allows for mistakes and disappointments. Though their relationship embodies the intergenerational conflict between second-wave feminists and their female offspring, it is also representative of the general dynamics between mothers and daughters that encompasses unmet expectations on both parts:

You were a wanted child. [...] She would say this a little regretfully, as though I hadn't turned out entirely as she'd expected. No mother is ever, completely, a child's idea of what a mother should be, and I suppose it works the other way around as well. But despite everything, we didn't do badly by one another, we did as well as most.

I wish she was here, so I could tell her I finally know this. $(1985,190)$

Offred's love for her mother, though never overtly expressed in the novel, is crucial to her identity. By initially rejecting her mother and her feminist ideals, Offred inadvertently succumbed to the rule of the father, represented here by the right-wing tendencies that led to the foundation of the Republic of Gilead and the enslavement of women. It is partly through the retrospective restoration and revaluation of their mother-daughter bond that Offred recovers her sense of self in the oppressive state of Gilead. As Luce Irigaray warns, "Neither little girl nor woman must give up love for their mother. Doing so uproots them from their identity, their subjectivity" $(1991,44)$. To discover her true Self, Offred must reconnect with her mother, even if it entails an internal monologue. The intergenerational transmission is sustained, or in Irigaray's terms, a genealogy of women is upheld.

\section{Offred as a Mother: Child Removal}

Unlike her mother, who had her at the age of thirty-seven, Offred gave birth to a daughter at the age of twenty-five. The main narrative is related by a thirty-three-year-old Offred, who has been separated from her eight-year-old daughter for three years and has no knowledge of her offspring's whereabouts. Thus, the protagonist's experience of motherhood can be divided into a five-year period of direct mothering and a three-year period of child deprivation. The reader does not learn that Offred is a mother until page forty-nine, when the memory of Offred's mother prompts the memory of having her daughter abducted. The juxtaposition of the reminiscences of her mother with those of her daughter is hardly coincidental and should 
be read in terms of intergenerational transmission. ${ }^{5}$ The mother and the daughter always serve as a woman's double - someone she once was and someone she might become. As Carl Jung notes, "every mother contains her daughter in herself and every daughter her mother, and ... every woman extends backwards into her mother and forwards into her daughter" (1980, 188). However, in The Handmaid's Tale intergenerational transmission is disrupted, since Offred's daughter is appropriated by the system allegedly for her own good. "She's in good hands, they said. With people who are fit. You are unfit, but you want the best for her. Don't you?" $(1985,49)$.

Aware that any act of open rebellion would either lead to her immediate death or result in postponed death through banishment to the Colonies, Offred takes no risks. When shown the picture of her daughter, who "looked like an angel, solemn, compact, made of air" (1985, 49), she exclaims: "You've killed her" $(1985,49)$. Hence, she symbolically enacts the death of her daughter. From this moment. the daughter will function more as a ghost-like figure, an intrapsychic entity rather than an actual person. "Maybe I do think of her as a ghost, the ghost of a dead girl, a little girl who died when she was five," Offred reflects $(1985,74)$.

The horror of the unknown and the perpetual deprivation seem to be replaced by the trauma of child loss and mourning. The symbolic death of her daughter is supposed to help Offred pre-empt the pain that drove Demeter insane because having a daughter abducted inevitably shatters the mother's world. Offred cannot let herself go mad with worry, let alone rage, because sanity is the only aspect of her life she can retain from her pre-Gilead past: "Sanity is a valuable possession; I hoard it the way people once hoarded money. I save it, so I will have enough, when the time comes" $(1985,119)$. To survive the atrocities inflicted by the Gileadean regime, Offred must forsake the memory of her daughter, but the repressed tends to reappear.

Though initially the protagonist may seem emotionally detached from her daughter, this reserved attitude is a defence mechanism, and does not amount to the absence of maternal love. The suppressed memories of her daughter repeatedly find their way to Offred's conscious mind, to be repressed anew. In the scene of bread-making, which reminds Offred of her own mothering, the smell of yeast poses a threat to the protagonist's faked integrity. It inadvertently evokes her old Self, whose integral part was motherhood: "It smells of me, in former times, when I was a mother. This is a treacherous smell, and I know I must shut it out" (1985, 57). If Offred is to survive, she must forsake her maternal role, both past and prospective. Even if she bears a child, she will never be allowed to mother it, for, as a Handmaid, she is reduced to a solely reproductive function. Oppressed because of her biological maternal potential, ironically, she will never be allowed to fulfill it on an emotional level. As an unfit, fallen woman, a Handmaid does not deserve to mother any child: "She'll be allowed to nurse the baby, for a few months, they believe in mother's milk. After that she'll be transferred, to

The dream in which the memory of Offred's daughter running towards her to be hugged and cuddled, followed by the appearance of her mother with a tray as in the olden days, may be read as another metaphor of the intergenerational transmission of motherhood. The mother-daughter dyad is always mirrored in the daughtergranddaughter relation.

6 A similar mechanism, which Atwood describes as the Third-Man Syndrome, is explored in Hag-Seed, in which the protagonist's dead daughter keeps him company as a result of unresolved inner conflict. In The Handmaid's Tale the daughter is still alive, but Offred does not have that knowledge or certainty until towards the end of the novel. 
see if she can do it again, with someone else who needs a turn. But she'll never be sent to the Colonies, she'll never be declared Unwoman. That is her reward" $(1985,137)$. In the Republic of Gilead, only morally upright women are granted the privilege of mothering.

Despite Offred's willed repression, her daughter comes back to her in dreams, of which the worst is that of their capture and separation. The dream she fears the most is less of a dream in Freud's terms than an actual recollection of their attempted escape to Canada. At the onset it is a dynamic description of the turbulent chase, during which Offred is "running," "pulling" and "dragging" $(1985,84)$ her daughter along until she begins to cry. The terror of potential capture is so intense that, fearing for their life, Offred "angrily" $(1985,85)$ hushes her daughter. Shots are fired nearby, and the scene metamorphoses into a slow-motion picture brimming with tenderness. Offred pulls her daughter down and shelters her with her body. Unfortunately, they are discovered, captured and separated. The violent nature of their arrest is unexpectedly counterbalanced by Offred's description of a red autumn leaf, and trees turning bare early. Such an incongruent juxtaposition shows that in order to cope with the traumatic experience of the loss of a daughter, Offred unwittingly resorts to dissociation. She detaches herself from the harrowing experience (or its memory) to numb the pain.

Dissociation is a defence mechanism that occurs outside the person's conscious mind and in its extreme form results in amnesia. Offred, however, cannot let herself forget her daughter, the most precious person in her life. When she says about the leaf that "[i]t's the most beautiful thing I've ever seen" $(1985,85)$, it is evident that she is not thinking about botanical details at such a tragic moment. In order to survive the unimaginable, the protagonist diverts her attention from her daughter, who obviously is "the most beautiful thing" she has ever seen, and projects it onto the leaf. Thanks to this mechanism, she survives the separation trauma and retains the memory of the last encounter with her daughter.

The price she must pay for distancing herself from the memory of loss is the subsequent detachment from her body and suicidal ideation. "I feel calm and floating, as if I'm no longer in my body" $(1985,85)$, says Offred, remembering the moment the two of them lay in hiding. Of all the emotions, tranquility is not a natural reaction to the threat of being caught; hence, suppressed rage and fear will soon induce Offred's depression. The unnatural composure and suicidal thoughts will accompany the protagonist almost to the end of the narrative, when she regains her body and awakens her deadened senses. It is impossible to determine whether Offred experienced dissociation during the capture, or perhaps, and more likely, enacted it afterwards. The main events in the novel take place three years after their arrest, yet the memory of her daughter "holding out her arms to [her], being carried away" $(1985,85)$ retains a strong grip on Offred's mind.

The news of her daughter, delivered to her surreptitiously in the form of a Polaroid picture, opens old wounds. Though on the one hand she rejoices that her daughter is well, on the other, she finds the photograph overwhelming. The painful realization that she has been eliminated from her daughter's life and erased from her memory makes her want to take her own life. The newly inflicted suffering is such that she wishes she had never been given that photograph: 
Time has not stood still. It has washed over me, washed me away, as if I'm nothing more than a woman of sand, left by a careless child too near the water. I have been obliterated for her. I am only a shadow now, far back behind the glib shiny surface of this photograph. A shadow of a shadow, as dead mothers become. You can see it in her eyes: I am not there. $(1985,240)$

The apprehension that her daughter does not remember her amounts to Offred's symbolic death. Forgotten by her daughter, she no longer participates in the intergenerational transmission even in the way dead mothers do. While her own mother acts as an entity within Offred's psyche, she herself is absent from her daughter's psyche and life. It is not until late in The Testaments that Offred is reunited with both her daughters outside Gilead. "She looked sad and happy, both at once" (2019, 399), observes Nicole upon their encounter. The eighteen- and fifteen-year-long separations from her daughters must have taken a toll on Offred's life. Although she knew that her offspring were safe, she still must have suffered the consequences of child removal. The happy ending is thus severely tinged with loss and regret on Offred's part.

\section{Offred's Daughters: Two Tales}

While a decade and a half separates Offred's narrative from that of her daughters, the time lapse between the publication of The Handmaid's Tale and its sequel is thirty-four years and encompasses significant shifts in the women's liberation movement. In 1985, postfeminism was gaining strength; the world since 2019 has already seen the transformation of 1990s third-wave feminism into its fourth wave (Chamberlain 2017; Rivers 2017). Although The Testaments may be viewed as a response to the global crisis in equal treatment of sexes that consolidated the emergence of fourth-wave feminism, it is difficult to read the sequel's characters as representative of this movement, since the movement relies heavily on popular culture, modern technology and social media (Rivers 2017, 5). Therefore, I invite the reading of The Testaments in a dialectic relationship to The Handmaid's Tale and, consequently, as a literary realization of the third-wave agenda of diversity and empowerment.

The shift in narration from the single voice of Offred into three parallel first-person narratives - Aunt Lydia, Agnes Jemima and Nicole/Jade - answers the third-wave feminists' urge to contest the essentialist understanding of womanhood. As Dicker and Piepmeier argue, "the third wave operates from the assumption that identity is multifaceted and layered. Since no monolithic version of 'woman' exists, we can no longer speak with confidence of 'women's issues'; instead we need to consider that such issues are as diverse as the many women who inhabit our planet" $(2003,10)$. Since the novel consists of the interspersed testimonies of three different women, their stories differ significantly in terms of life experience, language and narrative techniques, imitating successfully the way these characters see the surrounding world, and expanding the definition of female experience and womanhood. Despite running on different tracks, all are feminist narratives that manifest the complexity of feminist awakening and activism. In this respect, they echo Budgeon's observation about third-wave specificity: "the positive effect of opening out definitional boundaries is seen to be an increased awareness and recognition of the diffuse spaces within which feminist identities are now 
being practised. It is argued that there are numerous ways in which one may be a feminist and that there is no one 'right' way of being one" (2011b, 282). To exemplify, Aunt Lydia resolves to use the power she has gained through collaboration with the Gileadean regime to overthrow it, thus positioning herself firmly on the women's side - to the astonishment of The Handmaid's Tale's readers. Agnes Jemima forms her feminist identity first through the rejection of a Wife role, then by learning to read and subsequently studying books kept beyond reach of Gileadean women except Aunts. Hers, then, is the journey through knowledge. Nicole/Jade, on the other hand, is already a self-aware feminist at the beginning of The Testaments. Having grown up in quasi contemporary Canada, she is a self-empowered teenager who, thanks to her adoptive parents and the school she attended, knows she should always "stand up against injustice" $(2019,52)$. She understands that the personal is political, and actively participates in rallies against Gilead as well as environmental protests that echo current youth climate strikes.

The most astounding and confounding aspect of The Testaments, however, is the bold refashioning of the character of villainous Aunt Lydia from The Handmaid's Tale and casting her in the role of Gilead's nemesis. Through the rehabilitation of this character - which raises a multitude of ethical questions inherent in a narrative of involuntary collaboration - Atwood underscores the need for women's solidarity, the notion that was persistently addressed and found lacking in the lives of her characters up to the publication of the Maddaddam trilogy. The discovery of the statue dedicated to Becka, Agnes Jemima’s best friend, who sacrificed her life so that Agnes and Nicole could escape Ardua Hall and expose the corrupt face of Gilead, is an unambiguous tribute to women's solidarity that seems to extend the fictional world. The inscription, "this memorial was erected by her sisters" $(2019,415)$ and "in recognition of the invaluable services provided by A.L.," that is Aunt Lydia, is a conspicuous assertion of the value of sisterhood, so much urged by the second wave. ${ }^{7}$

It is necessary again to draw a distinction between feminist solidarity and the postfeminist girlfriend culture that rose to prominence after the turn of the century and is epitomized by the American TV series Sex and the City. In her Girlfriends and Postfeminist Sisterhood, Alison Winch argues that "girlfriend culture revolves around homosocial forms of control where women bond through the bodies of other women"; the resulting friendships are insidious for being "marketed as solidarity" and "promoted as entitlement and strength" $(2013,5)$. In a postfeminist model of sisterhood, women support their carefully selected friends in a common struggle to attain the feminine ideal, predominantly understood as a desirable thin body. ${ }^{8}$ The sisterhood Atwood seems to endorse derives from second-wave feminism but is informed by third-wave critique of the term as "fundamentally flawed, because it emerged

The narrative frame of two statues, one of Aunt Lydia erected by Gilead in recognition of her services, described in the novel's opening, and one commissioned by Agnes and Nicole at the very end seem to question the validity of historiography's study of monuments as artefacts, warning the reader not to trust them implicitly. I see this frame, however, primarily as part of Atwood's dispute with Professor Pieixoto over history writing, which privileges grand narratives and hard data rather than witness testimonies.

8 "As a replacement for feminist solidarity, young women are offered highly individualized but supposedly newly empowered subject positions, from which to engage in practices of self-invention offered by consumer culture and rewarded recognition by neoliberal discourses that attach labels of success to those who take up these forms of subjecthood" (Budgeon 2011a, 67). 
from women liberationists who did not acknowledge the extent to which women oppress other women" (Evans 2015, 112). The character of Aunt Lydia further complicates this definition, since she "is happy to destroy women who have internalised the values of the patriarchal regime" (Enright 2019).

The novel's sisterhood, then, is no longer based on gender sameness but on feminist subjectivity and "stresses the commonality amongst and between a large and diverse group of activists committed to eradicating sexism" (Evans 2015, 113). Interestingly, the old-fashioned outfit of the Pearl Girl in which sculpted Becka is clad is reminiscent of suffragettes, whose goals were the right to vote and own property as well as access to education. Those fundamental gains attained by the first wave were the first rights to be denied to women by the Republic of Gilead, regressing society to the 19th century. The overlap of these seemingly disparate feminist waves in the world of Gilead poignantly captures the contemporary world, in which countries that have seen the emergence of fourth-wave feminism are taking a dangerously retrogressive step towards curbing women's autonomy, while in some societies, demanding access to education is still a radical feminist position. ${ }^{9}$ Present day feminist solidarity, therefore, must allow for the plurality of feminisms and recognize that it is "a dynamic and responsive ideology that attempts to resist essentialism and universalizing, in order to adapt to women's ever-changing experiences and a continually shifting political landscape" (Rivers $2017,3)$ and whose "aim is not to develop a feminism which makes representational claims on behalf of women but to advance a politics based upon self-definition and the need for women to define their personal relationship to feminism in ways that make sense to them as individuals" (Budgeon 2011b, 273).

This complexity of female experience is demonstrated through the life stories of Offred's daughters; for fifteen years their stories separate The Handmaid's Tale from its sequel, developing along two divergent paths. Agnes Jemima grows up in the Republic of Gilead as a Commander's daughter, whereas baby Nicole is brought up in Canada by a couple belonging to a resistance movement. In the main plotline of The Testaments, they are twenty-three and sixteen years old, respectively. The character of Nicole, alias Jade, resembles Atwood's characters such as Sabrina Chase from The Blind Assassin or Anne Marie from Hag-seed, who epitomize a new woman in town who is not in thrall to traditional gender roles. They know what they want and are confident enough to achieve it against people's expectations, let alone approval. Compared with Atwood's pre-MaddAddam female characters, they represent hope for a better future. After all, the fall of Gilead would not have occurred but for Nicole/Jade, whose undercover name means a precious green stone, signifying hope, "purity and serenity" as well as "wisdom gathered in tranquility." Jade "integrates the mind with the body," "promotes self-sufficiency" and "encourages you to become who you really are" (Hall 2003, 152). Thus, Atwood endows her youngest female character in the novel with a talisman to aid her identity formation in accordance with her body but on her own terms. Nicole knows that her anatomy does not determine her destiny, and therefore at the age of sixteen, unlike her sister who grew up in Gilead, she has not given prospective wifehood or motherhood much thought.

See the Nobel Peace Prize Winner Lecture by Malala Yousafzai: https://www.nobelprize.org/prizes/peace/2014/ yousafzai/26074-malala-yousafzai-nobel-lecture-2014/. 
Contrary to Nicole, Agnes Jemima is forced to contemplate and prepare for wifehood and subsequent motherhood from her early years. Her marriage is arranged when she turns thirteen, which is considered the optimal age to produce a subservient wife: "Thirteen is not too young. It all depends," says one of the Aunts, "It does wonders for them if we can find a proper match. They settle right down" $(2019,154)$. Unlike some of her friends, who look forward to getting married in order to rise in the world, Agnes and her best friend Becka fear the physical aspects of marital sex and the loss of self in a marital union. The former confesses: "my reaction had been more like disgust and loathing, and now seemed to me trivial in view of Becka's genuine horror. She really did believe that marriage would obliterate her. She would be crushed, she would be nullified, she would be melted like snow until nothing remained of her" $(2019,163)$. This grim view of the wife's role and fate, which stands in opposition to the officially glorified Wife status propagated by the state of Gilead, obviously stems from the gap between propaganda and reality. Both Agnes and Becka recognize that wives are not free either, and must forsake themselves in order to fulfill their roles obediently.

Incorporating the Bluebeard syndrome into her latest novel, embodied by Commander Judd, whose "Wives have a habit of dying" and who "is a great believer in the restorative powers of young women" $(2019,63)$, Atwood reiterates her long-standing warning against "societal acceptance of women's victim role" and "the actuality of sexual relationships as sites of confrontation and, all too often, of legitimate female fears" (Barzilai 2005, 251-52). In Gilead the ubiquity of sexist violence that encompasses all women regardless of their status is foregrounded by the sexual harassment both Agnes and Becka experience from the father of the latter. The severity of sexual abuse drives Becka towards suicide once she learns she is to be married off soon; the vision of marriage and sex annihilates her. Luckily, she is rescued and, thanks to Aunt Lydia, given a chance to become part of the Ardua Hall community. Similarly, Agnes, who is elected to become the new wife of Commander Judd, is spared the fate of her predecessors by rejecting marriage altogether and claiming to have a religious calling. Hence, both girls liberate themselves from their gendered roles of prospective Wives by electing the path of an educated, single Aunt. Their choice of knowledge, resentful of postfeminist ideology of domesticity, is the first step towards their feminist subjectivity and belies Aunt Lydia's assertion from The Handmaid's Tale that "For the ones who come after you, it will be easier. They will accept their duties with willing hearts" $(1985,127)$.

Notwithstanding the strong presence of Offred in The Testaments, although reliant on the reader's ability to unite narrative strands, her perspective in the sequel is obliterated. It is clearly no longer The Handmaid's Tale. The reader never finds out the emotional cost of separation from her daughters. Sadly, Offred was right to worry that her older daughter would forget her and she would sink into oblivion, for "very young children may be unable to recall adverse events that occurred during their earliest years, not because the experience was so traumatic that it has been blocked out of awareness but because next to nothing is remembered from these years anyway, thanks to childhood amnesia" (McNally 2005, 820). Agnes Jemima grows up "loved and cherished" $(2019,9)$ by her mother Tabitha, the Wife of Commander Kyle. Whether out of fear that the child might eventually recall the violent separation from her biological mother or for some other reason, Tabitha invents a fairy talecum-memory according to which she rescued the girl from evil child-kidnapping witches 
that lived in an enchanted castle surrounded by the forest. Since Agnes was five when she was taken from her mother, and the circumstances of her removal overlapped with Tabitha's story, she incorporated this elaborate lie. "I did have a hazy memory of running through the forest with someone holding my hand. Had I hidden in a hollow tree? It seemed to me that I had hidden somewhere. So maybe it was true," she assumes $(2019,12)$.

While Offred held on to the memory of their violent separation, though attempting to detach herself from the painful feelings it roused, Tabitha's story superseded Agnes's actual reminiscence and erased the memory of her pre-Gilead mother. Yet, the moment her friends reveal the truth about her real mother being a Handmaid and their escape attempt, Agnes slowly starts to recall, or rather reconstruct, the circumstances of the chase. The retrieved memory becomes evidence of her mother's love and determination: "She must have loved me or she wouldn't have tried to take me with her when she was running away" (2019, 90). The reminiscence of the foiled escape from The Handmaid's Tale, which operates as a traumatic threshold between a felicitous pre-Gilead past and an oppressive Gilead present, encapsulating Offred's original loss and despair, is thus rewritten in The Testaments as a tale of the power of maternal feeling, foreshadowing the ultimate mother-daughter reunion.

In the proceedings from the Thirteenth Symposium on Gileadean Studies that conclude The Testaments, Professor Pieixoto takes the reader beyond the timeline of the Agnes and Nicole narratives. Building on other data he has found that corroborate the two witness testimonies, as if they were insufficient evidence per se, in a condescending manner reminiscent of The Handmaid's Tale, the professor concludes: "our two young messengers must indeed have lived not only to tell their tale but also to be reunited with their mother and their respective fathers, and to have children and grandchildren of their own" $(2019,415)$. In this view, both Agnes and Nicole eventually chose motherhood and inscribed themselves in the intergenerational transmission of motherhood. Out of the reach of Gilead and its oppressive gender norms, Agnes is thought to have discovered the feminist assertion that lies at the heart of both novels, namely, motherhood is not and should not be a must but a choice.

\section{Conclusion}

Tales of mothers and daughters are inevitably inscribed in the intergenerational pattern of transmission, assuming that the mother is a pivotal point of reference for the daughter's identity formation (Boyd 1989). While the notion of womanhood received by the daughter from her maternal parent is affected by personal experience and circumstances, it is also representative of the mother's generation of women. Such is the case for Offred and her radical feminist mother, whose tale demonstrates the conflict between second-wave feminists and their postfeminist daughters. The Testaments, thankfully, restores hope in the power of feminist movements, since all the primary characters - Offred, her daughters and, unexpectedly, Aunt Lydia - eventually develop feminist subjectivities. The reading of The Testaments as an embrace of a third-wave message does not preclude influence from and echoes of an emerging fourth wave, especially since the Handmaids' "red and white robes adopted as a symbol of female defiance from Ireland to Argentina, but most often in the US" have become a global landmark of this new wave (Atwood 2019b). The distinction 
between the two latest surges of feminism nonetheless becomes less significant if we take under scrutiny the wave narrative of feminism as such. As Chamberlain observes, "One wave does not obliterate the other, and waves do not neatly end, with a coherent finishing point that inevitably leads to a renewed surge of activism years later" $(2017,30)$. What seems to be of utmost importance in a reading of The Handmaid's Tale and The Testaments is the distinction between feminism(s) and postfeminism, which, though transformed and now masquerading as girlfriend culture, holds strong.

\section{References}

Alford, Allison M., and Meredith Marko Harrigan. 2019. "Role Expectations and Role Evaluations in Daughtering: Constructing the Good Daughter." Journal of Family Communication 19 (4): 348-61. https://doi.org/10.1080/15267431.2019.1643352.

Allit, Patrick. 2016. "Phyllis Schlafly: American feminism's great anti-heroine.” The Spectator, September 10, 2016. https://www.spectator.co.uk/article/death-of-an-anti-feminist.

Atwood, Margaret. (1985) 1987. The Handmaid's Tale. London: Virago Press.

-. 2019a. The Testaments. London: Chatto \& Windus.

—. 2019b. "Margaret Atwood: For a long time we were moving away from Gilead." Interview by Lisa Allardice. The Guardian, September 20, 2019. https://www.theguardian.com/books/2019/sep/20 /margaret-atwood-moving-away-from-gilead-testaments.

Badinter, Elisabeth. 2011. The Conflict. How Modern Motherhood Undermines the Status of Women. Translated by Adriana Hunter. New York: Metropolitan Books.

Barzilai, Shuli. 2005. “The Bluebeard Syndrome in Atwood's Lady Oracle: Fear and Femininity.” Marvels \& Tales 19 (2): 249-73.

Bloom, Harold. 2004. Margaret Atwood's The Handmaid's Tale: Bloom's Guides. New York: Chelsea House. Bouson, J. Brooks. 1993. “The Misogyny of Patriarchal Culture in The Handmaid's Tale." In Brutal Choreographies: Oppositional Strategies and Narrative Design in the Novels of Margaret Atwood, 135-58. Amherst, MA: University of Massachusetts Press.

Boyd, Carol J. 1989. "Mothers and Daughters: A Discussion of Theory and Research." Journal of Marriage and Family 51 (2): 291-301. https://doi.org/10.2307/352493.

Braithwaite, Ann. 2002. "The personal, the political, third-wave and postfeminisms." Feminist Theory 3 (3): 335-44. https://doi.org/10.1177\%2F146470002762492033.

Brans, Jo. 2006. "Using What You're Given." In Waltzing Again: New and Selected Conversations with Margaret Atwood, edited by Earl G. Ingersoll, 79-89. Princeton, NJ: Ontario Review Press.

Budgeon, Shelley. 2011a. Third Wave Feminism and the Politics of Gender in Late Modernity. London: Palgrave Macmillan.

—. 2011b. "The Contradictions of Successful Femininity: Third-Wave Feminism, Postfeminism and 'New' Femininities." In New Femininities: Postfeminism, Neoliberalism and Subjectivity, edited by Rosalind Gill and Christina Scharff, 279-92. New York: Palgrave Macmillan.

Chamberlain, Prudence. 2017. The Feminist Fourth Wave: Affective Temporality. London: Palgrave Macmillan.

Chodorow, Nancy J. 1999. The Reproduction of Mothering. Berkeley: University of California Press.

Chodorow, Nancy J., and Susan Contratto. 1989. “The Fantasy of the Perfect Mother." In Feminism and Psychoanalytic Theory, edited by Nancy J. Chodorow, 79-96. New Haven: Yale University Press.

Cixous, Hélène. 1976. "The Laugh of the Medusa.” Translated by Keith and Paula Cohen. Signs 1 (4): 875-93. https://www.jstor.org/stable/3173239.

Dicker, Rory, and Alison Piepmeier. 2003. “Introduction." In Catching a Wave: Reclaiming Feminism for the 21st Century, edited by R. Dicker and A. Piepmeier, 3-28. Boston: Northeastern University Press.

Ducret, Diane. 2016. Zakazane ciato. Historia męskiej obsesji. Kraków: Znak Horyzont. 
Enright, Anne. 2019. “The Testaments by Margaret Atwood review: A dazzling follow-up to The Handmaid's Tale." The Guardian, September 10, 2019. https://www.theguardian.com/books/2019/sep/10/thetestaments-by-margaret-atwood-review.

Evans, Elizabeth. 2015. The Politics of Third Wave Feminisms: Neoliberalism, Intersectionality, and the State in Britain and the US. London: Palgrave Macmillan.

Faludi, Susan. 2006. Backlash: The Undeclared War Against American Women. New York: Three Rivers Press.

Gamble, Sarah. 2006. "Postfeminism." In The Routledge Companion to Feminism and Postfeminism, edited by Sarah Gamble, 36-45. New York: Routledge.

Hall, Christopher. 2011. "Beyond Kübler-Ross: Recent developments in our understanding of grief and bereavement." InPsych 33 (6). https://www.psychology.org.au/formembers/publications/inpsych/2011/dec/Beyond-Kubler-Ross-Recent-developments-in-our-und.

Hall, Judy. 2003. The Crystal Bible. Cincinnati: Walking Stick Press.

Heywood, Leslie, and Jennifer Drake. 1997. "Introduction." In Third Wave Agenda: Being Feminist, Doing Feminism, edited by Leslie Heywood and Jennifer Drake, 1-20. Minneapolis: Minnesota University Press.

Hogsette, David S. 1997. "Margaret Atwood's Rhetorical Epilogue in The Handmaid's Tale: The Reader's Role in Empowering Offred's Speech Act." Critique: Studies in Contemporary Fiction 38 (4): 262-78.

Howells, Coral Ann. 1996. Margaret Atwood. London: Macmillan Press.

-. 2005. Margaret Atwood. Second Ed. New York: Palgrave Macmillan.

Irigaray, Luce. 1991. "The Bodily Encounter with the Mother." In The Irigaray Reader, edited by Margaret Whitford, 34-46. Translated by David Macey. Oxford: Basil Blackwell.

Jung, Carl Gustav. 1980. The Archetypes and the Collective Unconscious. Collected Works. Volume 9 Part I. Translated by G. Adler and R.F.C. Hull. Princeton, NJ: Princeton University Press.

Malak, Amin. 1987. "Margaret Atwood's The Handmaid's Tale and the Dystopian Tradition." Canadian Literature 112: 9-15.

McNally, Richard J. 2005. "Debunking Myths about Trauma and Memory." Canadian Journal of Psychiatry 50 (13): 817-22. https://doi.org/10.1177/070674370505001302.

Miller, Eric C. 2015. "Phyllis Schlafly's 'Positive' Freedom: Liberty, Liberation, and the Equal Rights Amendment." Rhetoric \& Public Affairs 18 (2): 277-300.

Neuman, Shirley. 2006. “Just a Backlash': Margaret Atwood, Feminism, and The Handmaid's Tale." University of Toronto Quarterly 75 (3): 857-68. https://doi.org/10.1353/utq.2006.0260.

Rivers, Nicola. 2017. Postfeminism(s) and the Arrival of the Fourth Wave. Turning Tides. London: Palgrave Macmillan.

Rossi, Alice S. 1977. "A Biosocial Perspective on Parenting." Daedalus 106 (2): 1-31.

Schlafly, Phyllis. 2003. "The Positive Woman Knows Who She Is." In The Columbia Documentary History of American Women Since 1941, edited by Harriet Sigerman. 323-25. New York: Columbia University Press.

Tolan, Fiona. 2005. "Feminist Utopias and Questions of Liberty: Margaret Atwood's The Handmaid's Tale as Critique of Second Wave Feminism." Women: A cultural review 16 (1): 18-32.

- 2007. Margaret Atwood: Feminism and Fiction. Amsterdam \& New York: Rodopi.

Winch, Alison. 2013. Girlfriends and Postfeminist Sisterhood. London: Palgrave Macmillan.

Wolf, Naomi. 2003. Misconceptions. Truth, Lies, and the Unexpected on the Journey to Motherhood. New York: Anchor Books. 